\title{
ISOLATION AND IDENTIFICATION OF FUNGI WITH POTENTIAL FOR BIOLOGICAL STUMP REMOVAL OF EUCALYPTUS SPP.
}

\author{
Costa $\mathrm{LG}^{1,}$ *, Paes JB ${ }^{1}$, Jesus Junior $\mathrm{WC}^{2}$, Brocco VF ${ }^{1} \&$ Pinho $\mathrm{DB}^{3}$ \\ ${ }^{1}$ Department of Forest and Wood Science, Federal University of Espirito Santo, Governador Lindemberg, 316, 29550-000, Jerônimo \\ Monteiro, Espirito Santo, Brazil \\ ${ }^{2}$ Lagoa do Sino Academic Department, Federal University of São Carlos, Aracaçu, 18290-000, Buri, São Paulo, Brazil \\ ${ }^{3}$ Department of Phytopathology, University of Brasília, Asa Norte, 70910-900, Brasília, Distrito Federal, Brazil
}

*lais-costa1@live.com

Submitted May 2019; accepted September 2019

\begin{abstract}
This study aimed to identify and evaluate the decay capability of fungi that occur naturally in eucalyptus plantations of three cities in Espírito Santo state, Brazil. Hence, discs from deteriorated stumps were collected and samples isolatied to obtain pure fungal cultures. An experiment using Petri dishes with malt-agar medium and eucalyptus sapwood was performed in order to test the decay of each isolate. The experiment was evaluated by mass loss every four weeks during a total of 20 weeks. Fungi with decay capability were selected and identified via extraction of genomic DNA. Seven isolates were identified: Penicillium implicatum, Resinicium confertum, Phanerochaete chrysosporium, Cladosporium sp., Penicillium sp., Trichoderma citrinoviride and Acremonium sp. Isolation and identification of fungi from eucalyptus stumps provided naturally occurring decay fungi that inhabit the eucalyptus plantations that were adapted for this study.
\end{abstract}

Keywords: Fungi selection, molecular identification, stump decay, wood-decaying fungi

\section{INTRODUCTION}

Fungi capable of causing changes in the physical and mechanical properties of wood are found in the phylum of Basidiomycota, Ascomycota and Deuteromycota (Kluczek-Turpeinen et al. 2005, Liers et al. 2011, Riley et al. 2014). The basidiomycetes include mushrooms, plant and animal pathogens, and saprophytic fungi. This phylum has the main decomposers of terrestrial ecosystems (Urairuj et al. 2003).

The wood degrading fungi, Basidiomycetes, vary mainly in relation to their lignocellulolytic capacity, and is classified as white-rot or brownrot fungi (Tortella et al. 2008). The fungi causing white-rot use hydrolases that gradually degrade cellulose and lignin, and mineralise then to $\mathrm{CO}_{2}$ and $\mathrm{H}_{2} \mathrm{O}$ with peroxidase enzymes, while brown-rot fungi rapidly depolymerise cellulose, and lignin remains as residue (Martínez 2002).

Ascomycetes and Deuteromycetes, capable of decaying wood, are classified as soft-rot fungi which mainly affect the external surface of wood, leaving it darkened and soft, with the presence of transverse cracks when dried (Hatakka \&
Hammel 2010). These fungi are problematic on wood and wood-based materials, but also may have potential for beneficial biodegradation, such as biopulping or bioincising (Wu et al. 2005, Franco et al. 2006, Çöpür \& Tozluoğlu 2007, Mendonça et al. 2008, Schubert et al. 2011, Thaler et al. 2012). Another beneficial application for processes involving wood is the biological stump removal in forest plantations, whereby xylophagous fungi accelerate the process of deterioration of the stumps that remained after the trees were harvested (Alonso et al. 2007, Andrade et al. 2012, Negrão et al. 2014, Silva et al. 2014).

The process of stump removal in forest plantations is an important step to clean the area for replanting. This process is usually performed mechanically with the use of implements and machines. Mechanical stump removal increases costs, besides causing damages to the soil by increasing the degree of compaction and removal of nutrients during the displacement of the organic blanket which accumulates on the surface (Alonso et al. 2007, Hope 2007). 
Due to large areas of eucalyptus plantations in Brazil, the improvement of techniques used in this sector has been increasingly researched, always aiming at reducing costs and damage to the environment. As such, biological stump removal using wood-decaying fungi appears as a sustainable and affordable alternative for substituting the process of mechanical stump removal. Thus, the present study aimed to identify and evaluate the deteriorating potential of fungi that occur naturally in eucalyptus plantations located in three municipalities in Espírito Santo, Brazil.

\section{MATERIALS AND METHODS}

\section{Collection of material and isolation of fungi}

Discs $( \pm 3.0 \mathrm{~cm}$ thickness $)$ of deteriorated stumps were collected in three municipalities in Espírito Santo, Brazil: Cachoeiro de Itapemirim $\left(20^{\circ} 46^{\prime} \mathrm{S}\right.$, $41^{\circ} 18^{\prime} \mathrm{W}, 100 \mathrm{~m}$ ), São José do Calçado (2055' S, $\left.41^{\circ} 37^{\prime} \mathrm{W}, 590 \mathrm{~m}\right)$ and Jerônimo Monteiro $\left(20^{\circ} 51^{\prime}\right.$ $\mathrm{S}, 41^{\circ} 27^{\prime} \mathrm{W}, 800 \mathrm{~m}$ ). The materials were properly identified and stored in bags of porous paper. For the isolation of fungi, the disks were transformed into samples measuring approximately $1.0 \times 1.0$ $\times 3.0 \mathrm{~cm}($ radial $\times$ tangential $\times$ longitudinal $)$, removed from the transition area which is located between the healthy and decomposed portions.

The indirect isolation of the fungi was carried out in a laminar flow chamber, where the samples were disinfected in sodium hypochlorite solution (2\%) for 15 seconds, washed in sterile distilled water, rapidly flamed and aseptically transferred to Petri dishes containing malt:agar $(2: 1.5 \%)$ culture media, on the basis of one sample per plate (Alonso et al. 2007, Alfenas et al. 2016).

Petri dishes were placed in an incubation room $\left(25 \pm 2{ }^{\circ} \mathrm{C}\right.$ and $65 \pm 5 \%$ relative humidity) in the absence of photoperiod, until fungi mycelial growth was observed. Isolation was conducted to obtain pure cultures by transferring fungi structures (spores and hyphae) to Petri dishes containing malt agar culture media.

\section{Evaluation of deterioration potential}

The objective of this experiment was to test the deterioration potential of each isolate and to select those with the greatest potential for field tests, as presented by Costa et al. (2017). In addition to the isolates from the field, three fungi with recognised deterioration capacity were used as positive controls, i.e, Trametes versicolor (Mad 697) (white-rot) and two brown-rot fungi, Postia placenta (Mad 698) and Gloeophyllum trabeum (Mad 617). In addition, two basidiomycetes that presented satisfactory deterioration capacity in a previous study were also used Silva et al. (2014).

During the assembly of the experiment, five Petri dishes were used containing the respective malt:agar culture media for each fungus mentioned above. Sapwood samples of Eucalyptus grandis $\times$ Eucalyptus urophylla (rotational age six years) with dimensions $1 \times 1$ $\times 1 \mathrm{~cm}$ (radial $\times$ tangential $\times$ longitudinal) were used to test the deterioration capacity of the isolates.

The wood samples were oven-dried at $103 \pm$ $2{ }^{\circ} \mathrm{C}$ for 48 hours, weighed to obtain the initial dry mass and then autoclaved. After 15 days, the time required for the mycelial growth of the fungus throughout the Petri dish in a laminar flow chamber, the wood samples were rapidly wetted in sterile distilled water and placed in the ratio of 10 samples per Petri dish.

The Petri dishes were incubated (25 \pm $2{ }^{\circ} \mathrm{C}$ and $65 \pm 5 \%$ relative humidity) in the absence of photoperiod. The experiment lasted for 20 weeks where evaluation was carried out every four weeks. At the end, the wood samples were removed from the Petri dishes and the mycelium was brushed off, and then oven-dried at $103 \pm 2{ }^{\circ} \mathrm{C}$ for 48 hours to obtain the final dry mass and mass loss (\%) (Figure 1).

\section{Molecular identification of fungi with potential for deterioration}

The fungi with potential for wood deterioration were selected and sent for molecular identification in the Laboratory of Seed Pathology and PostHarvest, Department of Plant Pathology, Federal University of Viçosa, Minas Gerais, Brazil.

The fungi were grown in potato dextrose agar (PDA) and kept in an incubator at $25 \pm 2{ }^{\circ} \mathrm{C}$ and $65 \pm 5 \%$ relative humidity for up to four weeks, depending on the growth rate of the isolate, and were subsequently sent for identification.

The mycelium of the isolate was removed with a scalpel and placed in $1.5 \mathrm{~mL}$ microtubes. The extraction of genomic DNA was performed using a Wizard ${ }^{\circledR}$ Genomic DNA Purification Kit, as described in Pinho et al. (2012). 


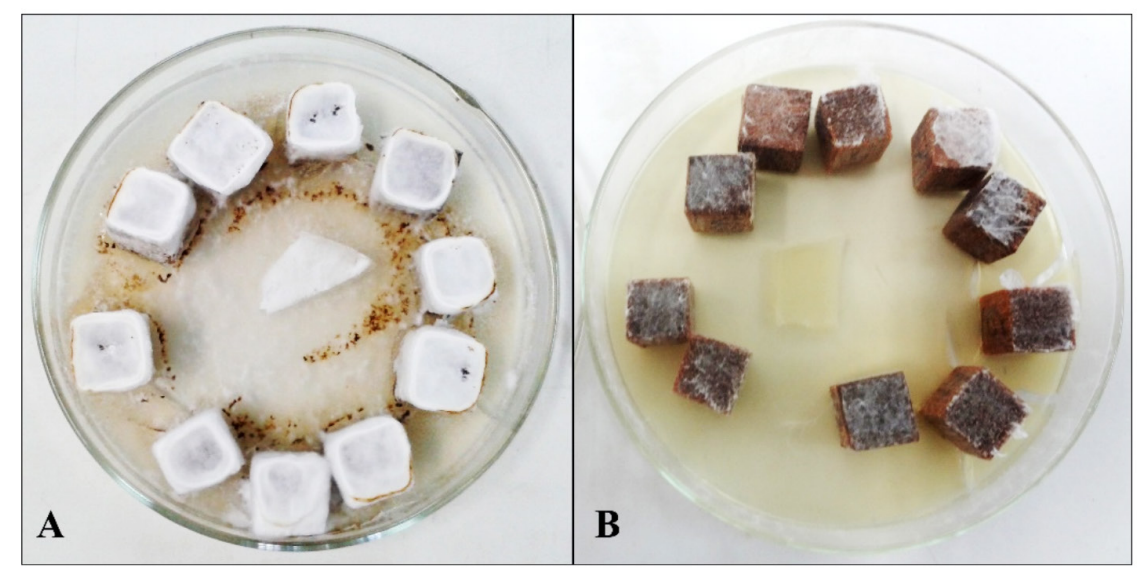

Figure 1 Wood blocks submitted to deterioration by Acremonium sp. (A) and Resinicium confertum (B) at the end of 16 and 4 weeks, respectively

The primers ITS1 (5'-TCGTCCGCTTATT GATATGC-3') and ITS4 (5'-GGAAGTAAAAGT CGTAACAAGG-3') were used to amplify the internal transcribed spacer (ITS) region of rDNA (White et al. 1990). Polymerase chain reaction (PCR) (amplicon) reactions included the following ingredients for each $25 \mu \mathrm{l}$ reaction: $12.5 \mu \mathrm{l}$ of $2 \mathrm{X}$ DreamTaq ${ }^{\mathrm{TM}}$ PCR Master Mix (MBI Fermentas, Vilnius, Lithuania), $1 \mu \mathrm{l}$ of $10 \mu \mathrm{M}$ of each forward and reverse primer synthesised by Invitrogen, $2 \mu \mathrm{L}$ of genomic DNA (25 ng $\mu \mathrm{l}-1)$, and nuclease-free water to complete the total volume.

The amplifications were performed with an initial denaturation at $94{ }^{\circ} \mathrm{C}$ for $5 \mathrm{~min}$, followed by 35 cycles of denaturation at $94{ }^{\circ} \mathrm{C}$ for $30 \mathrm{~s}$, annealing at $52{ }^{\circ} \mathrm{C}$ for $30 \mathrm{~s}$, initial extension at $72{ }^{\circ} \mathrm{C}$ for $30 \mathrm{~s}$ and a final extension of $7 \mathrm{~min}$ at $72{ }^{\circ} \mathrm{C}$. The amplified products were visualised on a $1 \%$ agarose gel to check the product size and purity. The PCR products were purified and sequenced by Macrogen, South Korea.

The nucleotide sequences were edited using the CodonCode Aligner software. All sequences were analysed and the arrangement of the nucleotides at ambiguous positions were corrected by comparison of sense and antisense sequences. The isolates were previously identified by analysis of the ITS sequences in the UNITE database (Nilsson et al. 2014).

\section{Analysis and evaluation of the results}

The potential of deterioration of the isolated fungi was evaluated as a function of the mass loss of the wood samples. For this, a completely randomised design was used in a factorial arrangement in which the effect of the isolated fungi and the time of exposure on mass loss (4, $8,12,16$ and 20 weeks) were analysed.

The Scott-Knott test at 5\% significance was used for factors detected as significant by the $\mathrm{F}$ test. The mass loss values were transformed into arcsen to meet the requirements of normality and homogeneity of variances.

\section{RESULTS AND DISCUSSION}

\section{Isolation and molecular identification of fungi with potential for deterioration}

Deteriorated discs of eucalyptus stumps collected from the field resulted in the isolation of 66 pure cultures, of which seven were taxonomically identified as being the ones that caused the greatest mass loss, and were therefore considered to have deterioration potential.

The seven isolates were Penicillium implicatum and Resinicium confertum from São José do Calçado, Phanerochaete chrysosporium from Jerônimo Monteiro, Cladosporium sp., Penicillium sp. and Trichoderma citrinoviride from Cachoeiro de Itapemirim, and Acremonium sp. (Silva et al. 2014), described as Basidiomycete 1 .

According to literature, Penicillium implicatum does not cause damage to wood. This fungus belongs to the phylum Ascomycota and is an important pathogen associated with the pomegranate fruit (Punica granatum), which has irregular patches of brown to caramel on the fruit bark (Labuda et al. 2004, Khokhar et al. 2013, Munhuweyi et al. 2016). 
There were no records on word deterioration potential of Resinicium confertum fungus, belonging to the phylum Basidiomycota. However, the Resinicium bicolor fungus, belonging to the same genus, causes white rot in wood. It is also used in industrial processes, for example in the biofibrillation of wood from Picea abies (Bredberg et al. 2002, Job 2002, Toljander et al. 2006, Nakasone 2007, Folman et al. 2008).

Phanerochaete chrysosporium, belonging to the phylum Basidiomycota, causes wood deterioration and is classified as a white rot fungus (FernandezFueyo et al. 2012, Skyba et al. 2016). This potential deteriorator was reported by Koyani and Rajput (2015) with Azadirachta indica wood, in which $P$. chrysosporium caused a mass loss of $29 \%$ after 120 days of exposure to this fungus.

The fungi of the genus Cladosporium, belonging to the phylum Ascomycota, are present in wood during deterioration process (Held et al. 2006, Kirker et al. 2012). The presence of this genus was described in plots of Pinus radiata treated with chromium copper arsenate (CCA), where the fungi Cladosporium oxysporum and Cladosporium sphaerospermum were identified as dominant species (Kim et al. 2007). There are also reports of the presence of $C$. cladosporoides in the deterioration of aged cotton fibers in museums, and the presence of Cladosporium sp. in the deterioration of pieces art in closed environments (Pangallo et al. 2009, Kavkler et al. 2015).

Fungi, from the genus Penicillium, are often consideredan causative agents in the deterioration of wood. This genus is commonly found in wood during the decomposition stage and internal environments, known as "internal moluds" (Clausen \& Yang 2007, Kirker et al. 2012). Penicillium chrysogenum, described as a soft rot fungus, is able to penetrate cell walls in less than a month, deteriorating cellulose, but not lignin (Hamed 2013).

The fungus Trichoderma citrinoviride, from the phylum Ascomycota, is commonly found in soil and decaying woods (Jeleń et al. 2014). It has the ability to deteriorate wood as it produces the main enzymes of cell wall decay, i.e. cellulases and xylanases (Blaszczyk et al. 2016). The fungus Trichoderma reesei, belonging to the same genus of the identified fungus, is classified as a soft rot fungus (Shrestha et al. 2009). In the study by Koyani et al. (2011), the white rot fungus, Trichoderma harzianum, caused $43 \%$ mass loss in Azadirachta indica wood after 120 days of exposure. The genus Acremonium has not been reported as a causative agent of wood rot. The Acremonium cucurbitacearum is responsible for the root rot and decline of melon vine (Cucumis melo), and Acremonium recife $i$ is the cause of rapid decline resulting from tree trunk decay of macadamia, (Ko 2009).

Among fungi with wood decay potential, brown- and white-rot fungi (basidiomycetes) provide greater structural damage to the wood cell wall (Ortiz et al. 2013). In the present study, $R$. confertum and $P$. chrysosporium belong to this class of fungi, therefore causing greater wood deterioration.

The other isolates belong to Ascomycota phylum, classified as soft-rot or mould with saprophytic characteristics in most of the aforementioned studies. Although these fungi have low or moderate wood decay capacity, they are capable of causing significant damage under favorable and long-acting conditions. Also, they are often part of the succession process of microorganisms that act together during wood decay process (Oliveira et al. 1986)

Only Acremonium sp. is presented as a phytopathogen, however, no citations were found for forest plantations. Isolates obtained from decaying stumps from local eucalyptus plantations minimise the potential for detrimental impact on land reuse for eucalyptus.

\section{Assessment of deterioration potential}

Analysis of variance indicated a significant difference between the fungus parameters, time and interaction of fungi $\mathrm{x}$ time. A comparison between means of mass loss in fungus $x$ time interaction, it was observed that mass loss in the first month was statistically the same for all fungi, except for P. placenta and T. citrinoviride, which had lowest means (Table 1).

In the second month, G. trabeum caused the highest mean mass loss, differing statistically from the others. Among the isolates obtained in the field, $P$. implicatum and $P$. chrysosporium achieved the second best performance, not statistically differing from T. versicolor, which obtained a $50 \%$ lower mass loss, compared to G. trabeum.

In the third and fourth months, G. trabeum and $T$. versicolor caused greater mass loss, differing statistically from others. In the fourth month, $P$. placenta did not differ from the previously 
Table 1 Comparison between the means of mass loss in wood samples as a function of time and fungi tested

\begin{tabular}{lccccc}
\hline \multirow{2}{*}{ Fungus } & \multicolumn{5}{c}{ Mass loss $(\%)$} \\
\cline { 2 - 6 } & \multicolumn{5}{c}{ Time (months) } \\
\cline { 2 - 6 } & 1 & 2 & 3 & 4 & 5 \\
\hline Trametes versicolor & $1.72^{\mathrm{aD}}$ & $4.90^{\mathrm{bC}}$ & $15.45^{\mathrm{aA}}$ & $12.13^{\mathrm{aB}}$ & $10.11^{\mathrm{B}}$ \\
Gloeophyllum trabeum & $0.66^{\mathrm{aD}}$ & $9.87^{\mathrm{aB}}$ & $12.62^{\mathrm{aA}}$ & $14.59^{\mathrm{aA}}$ & $6.57^{\mathrm{cC}}$ \\
Postia placenta & $0.01^{\mathrm{bD}}$ & $2.73^{\mathrm{cC}}$ & $4.68^{\mathrm{cC}}$ & $11.79^{\mathrm{aB}}$ & $17.23^{\mathrm{aA}}$ \\
Penicillium implicatum & $1.22^{\mathrm{aB}}$ & $6.37^{\mathrm{bA}}$ & $6.31^{\mathrm{bA}}$ & $7.62^{\mathrm{bA}}$ & $9.06^{\mathrm{bA}}$ \\
Resinicium confertum & $1.41^{\mathrm{aC}}$ & $3.29^{\mathrm{cB}}$ & $6.12^{\mathrm{bA}}$ & $3.70^{\mathrm{cB}}$ & $6.25^{\mathrm{cA}}$ \\
Acremonium sp. & $0.50^{\mathrm{aC}}$ & $2.84^{\mathrm{cB}}$ & $5.60^{\mathrm{bA}}$ & $5.72^{\mathrm{bA}}$ & $5.48^{\mathrm{cA}}$ \\
Phanerochaete chrysosporium & $0.80^{\mathrm{aB}}$ & $7.07^{\mathrm{bA}}$ & $0.85^{\mathrm{eB}}$ & $5.98^{\mathrm{bA}}$ & $5.02^{\mathrm{cA}}$ \\
Cladosporium sp. & $0.93^{\mathrm{aC}}$ & $4.01^{\mathrm{cB}}$ & $6.35^{\mathrm{bA}}$ & $2.80^{\mathrm{cB}}$ & $3.11^{\mathrm{dB}}$ \\
Penicillium sp. & $1.13^{\mathrm{aD}}$ & $2.58^{\mathrm{cC}}$ & $3.70^{\mathrm{cB}}$ & $8.14^{\mathrm{bA}}$ & $0.94^{\mathrm{eD}}$ \\
T.citrinoviride & $0.39^{\mathrm{bC}}$ & $1.33^{\mathrm{dC}}$ & $2.49^{\mathrm{dB}}$ & $1.62^{\mathrm{dB}}$ & $6.88^{\mathrm{cA}}$ \\
Mean & $0.84^{\mathrm{C}}$ & $4.91^{\mathrm{B}}$ & $6.17^{\mathrm{A}}$ & $7.25^{\mathrm{A}}$ & $6.38^{\mathrm{A}}$ \\
\hline
\end{tabular}

Means followed by the same lowercase (column) or uppercase (line) letter do not differ statistically; Scott-Knott test $\mathrm{p}>0.05$

analysed fungi. Among the fungi that presented the second best performance, Penicillium sp. obtained the best mean of mass loss, ie. $44 \%$ lower compared to G. trabeum.

In the fifth month, $P$. placenta obtained the highest mean of mass loss, differing statistically from others. Among the isolates from field, $P$. implicatum was prominent in relation to the others in the fifth month, not differing statistically from T. versicolor.

During the analysis of the mass loss for each fungus as a function of the months, it was observed that, T. versicolor and G. trabeum showed greatest mass losses in the third month, and a significant decrease in the fifth month. The $P$. placenta gradually increased mass loss a until the fifth month, reaching the largest mass loss among the fungi tested.

Among the isolated fungi in the field, it was observed that $P$. implicatum reached a higher mean of mass loss in the fifth month, however, no significant differences were observed during the second month of attack. A similar result was observed for $P$. chrysosporium, where the greatest loss occurred at the second month.

Among the other isolates tested, the greatest mass loss was reached after the third month of exposure, and some cases of decrease in subsequent months. Since the samples were mounted on different Petri dishes for each month, variations in samples and fungal attacks may have occurred. In all the fungi tested, it was observed that there was a significant increase in the mass loss until the third month, not differing statistically compared to the subsequent ones.

Monteiro and Freitas (1997) and Andrade et al. (2012) tested fungi deterioration capacity in a similar way to the one performed in this study, with Petri dishes and culture medium, finding potential fungi. Results from Monteiro and Freitas (1997) showed that, after eight weeks of exposure to G. trabeum, mass losses of $3.94,4.24,3.40,3.82$ and $24.91 \%$ was observed for corresponding wood of Astronium sp., Anadenanthera sp., Hymenaea sp., Aspidosperma polyneuron and Araucaria Angustifolia, respectively.

Andrade et al. (2012) isolated Polyporus guianensis, Pycnoporus sanguineus and Ganoderma applanatum from eucalyptus stumps in the field, which caused deterioration in Eucalyptus grandis wood, $0.03,29.0$ and $34.0 \%$, respectively, after eight weeks of exposure.

\section{CONGLUSIONS}

Isolation of fungi from eucalyptus stumps showed the genera and fungal species with deteriorating potential that inhabit eucalyptus plantations in the regions studied.

Based on the study and in literature, the method used to evaluate the deterioration capacity of isolated fungi allowed a faster and 
satisfactory selection of fungi with potential for deterioration, thus allowing the selected fungi to be tested by using other methodologies and even field experiments in order to know the realistic capacity of wood deterioration.

\section{REFERENCES}

Aegerter BJ, Gordon TR \& Davis RM. 2000. Occurrence and pathogenicity of fungi associated with melon root rot and vine decline in California. Plant disease 84: 224-230. doi:10.1094/PDIS.2000.84.3.224.

Alfenas AC, Ferreira FA, Mafia RG \& Gonçalves RCI. 2016. Isolamento de fungos fitopatogênicos. Pp 516 in Alfenas AC \& Mafia RG (eds) Métodos em Fitopatologia. $2^{\text {nd }}$ edition. Editora UFV, Viçosa.

Alonso SK, Silva AG, Kasuya MCM et al. Isolamento e seleção de fungos causadores da podridãobranca da madeira em florestas de Eucalyptus spp. com potencial de degradação de cepas e raízes. Revista Árvore 31: 145-155. doi:10.1590/S010067622007000100016.

Andrade Fa DE, Calonego FW, Severo ETd \& Furtado EL. 2012. Selection of fungi for accelerated decay in stumps of Eucalyptus spp. Bioresource Technology 110: 456-461. doi:10.1016/j.biortech.2012.01.069.

BŁaszczyk L, Strakowska J, CheŁkowski J, Gąbka-Buszek A \& KACZMAReK J. 2016. Trichoderma species occurring on wood with decay symptoms in mountain forests in Central Europe: genetic and enzymatic characterization. Journal of Applied Genetics 57: 397-407. doi:10.1007/s13353-015-0326-1.

Bredberg K, Erik Andersson B, Landfors E \& Holst O. 2002. Microbial detoxification of waste rubber material by wood-rotting fungi. Bioresource Technology 83: 221-224. doi:10.1016/S0960-8524(01)00218-8.

Chilosi G, Reda R, Aleandri MP et al. 2008. Fungi associated with root rot and collapse of melon in Italy. EPPO Bulletin 38: 147-154. doi:10.1111/j.13652338.2008.01200.x.

Clausen CA \& Yang V. 2007. Protecting wood from mould, decay, and termites with multi-component biocide systems. International Biodeterioration and Biodegradation 59: 20-24. doi:10.1016/j.ibiod.2005.07.005.

Çöpür Y \& Tozluoğlu A. 2007. The effect of AQ and NaBH4 on bio-kraft delignification (Ceriporiopsis subvermispora) of brutia pine chips. International Biodeterioration and Biodegradation 60: 126-131. doi:10.1016/j.ibiod.2007.05.009.

Costa LG, Paes JB, Jesus Junior Wc De, Brocco VF \& Furtado EL. 2017. Potential of selected fungi for biological stump removal of Eucalyptus spp. Forest Ecology and Management 402: 265-271. doi:10.1016/j. foreco.2017.07.054.

Fernandez-Fueyo E, Ruiz-Duenas FJ, Ferreira P et al. 2012. Comparative genomics of Ceriporiopsis subvermispora and Phanerochaete chrysosporium provide insight into selective ligninolysis. Proceedings of the National Academy of Sciences of the United States of America 109: 5458-5463. doi:10.1073/pnas.1119912109.

Folman LB, Kuein Gunnewiek PJA, Boddy L \& De Boer W. 2008. Impact of white-rot fungi on numbers and community composition of bacteria colonizing beech wood from forest soil. FEMS Microbiology Ecology 63: 181-191. doi:10.1111/j.1574-6941.2007.00425.x.

Franco H, Freer J, RodrÍguez J, Baeza J, Elissetche JP \& MENDONÇA R. 2006. Kraft pulping of Drimys winteri wood chips biotreated with Ganoderma australe. Journal of Chemical Technology and Biotechnology 81: 196-200. doi:10.1002/jctb.1383.

HAMED SAM. 2013. In-vitro studies on wood degradation in soil by soft-rot fungi: Aspergillus niger and Penicillium chrysogenum. International Biodeterioration and Biodegradation 78: 98-102. doi:10.1016/j. ibiod.2012.12.013.

HatakKa A \& Hammel KE. 2010. Fungal Biodegradation of Lignocelluloses. Industrial Applications. Springer Berlin Heidelberg, Berlin, Heidelberg. doi:10.1007/978-3642-11458-8_15.

Held BW, Jurgens JA, Duncan SM, Farrell RL \& Blanchette RA. 2006. Assessment of fungal diversity and deterioration in a wooden structure at New Harbor, Antarctica. Polar Biology 29: 526-531. doi:10.1007/ s00300-005-0084-3.

Hope GD. 2007. Changes in soil properties, tree growth, and nutrition over a period of 10 years after stump removal and scarification on moderately coarse soils in interior British Columbia. Forest Ecology and Management 242: 625-635. doi:10.1016/j. foreco.2007.01.072.

Jeleń H, Błaszczyk L, CheŁkowski J, Rogowicz K \& Strakowska J. 2014. Formation of 6-n-pentyl-2H-pyran-2-one (6PAP) and other volatiles by different Trichoderma species. Mycological Progress 13: 589-600. doi:10.1007/ s11557-013-0942-2.

Јов D. 2002. Assessment of selected decay Basidiomycetes for selective biodefibrillation of Picea abies wood. Mycological Progress 1: 123-129.

Kavkler K, Gunde Cimerman N, Zalar P \& Demšar A. 2015. Deterioration of contemporary and artificially aged cotton by selected fungal species. Polymer Degradation and Stability 113: 1-9. doi:10.1016/j. polymdegradstab.2015.01.004.

Khokhar I, Bajwa R \& Nasim G. 2013. New report of Penicillium implicatum causing a postharvest rot of pomegranate fruit in Pakistan. Australas. Plant Disease Notes 8: 39-41. doi:10.1007/s13314-013-0091-0.

Kim J-J, Kang S-M, Chor Y-S \& Kim G-H. 2007. Microfungi potentially disfiguring CCA-treated wood. International Biodeterioration and Biodegradation 60: 197-201. doi:10.1016/j.ibiod.2007.05.002.

Kirker GT, Wagner TL \& Diehl SV. 2012. Relationship between wood-inhabiting fungi and Reticulitermes spp. in four forest habitats of northeastern Mississippi. International Biodeterioration and Biodegradation 72: 18-25. doi:10.1016/j.ibiod.2012.04.011.

Kluczek-Turpeinen B, Steffen KT, Tuomela M, Hatakka A \& Hofrichter M. 2005. Modification of humic acids by the compost-dwelling deuteromycete Paecilomyces inflatus. Applied Microbiology and Biotechnology 66: 443-449. doi:10.1007/s00253-004-1677-4.

Ko WH. 2009. Nature of slow and quick decline of macadamia trees. Botanical Studies 50: 1-10.

Koyani RD \& RajPut KS. 2015. Anatomical characterisation of wood decay pattern in Azadirachta indica A. Juss. by the white-rot fungi Irpex lacteus Fr. (Fr.) and 
Phanerochaete chrysosporium Burds. Anales de Biología 37: 97-106.

Koyani RD, Sanghvi GV \& Rajput KS. 2011. Comparative study on the delignification of Azadirachta indica (L) Del., wood by Chrysosporium asperatum and Trichoderma harzianum. International Biodeterioration and Biodegradation 65: 179-184. doi:10.1016/j. ibiod.2010.10.010.

Labuda R, Hudec K, Piecková E, Mezey J, Bohovič R, Mátéová S \& Lukáč SS. 2004. Penicillium implicatum causes a destructive rot of pomegranate fruits. Mycopathologia 157: 217-223. doi:10.1023/ B:MYCO.0000020599.95040.c6.

Liers C, Arnstadt T, Ullrich R \& Hofrichter M. 2011. Patterns of lignin degradation and oxidative enzyme secretion by different wood- and littercolonizing basidiomycetes and ascomycetes grown on beech-wood. FEMS Microbiology Ecology 78: 91-102. doi:10.1111/j.1574-6941.2011.01144.x.

MARTínez AT. 2002. Molecular biology and structure-function of lignin-degrading heme peroxidases. Enzyme and Microbial Technology 30: 425-444. doi:10.1016/S01410229(01) 00521-X.

Mendonça RT, Jara JF, González V, Elissetche JP \& Freer J. 2008. Evaluation of the white-rot fungi Ganoderma australe and Ceriporiopsis subvermispora in biotechnological applications. Journal of Industrial Microbiology and Biotechnology 35: 1323-1330. doi:10.1007/s10295-008-0414-x.

Monteiro MBB \& Freitas AR. 1997. Método de ensaio acelerado para avaliação da durabilidade natural de madeiras. Revista Árvore 21: 555-561.

Munhumey K, Lennox CL, Meitz-Hopkins JC, Caleb OJ \& Opara UL. 2016. Major diseases of pomegranate (Punica granatum L.), their causes and management-a review. Scientia Horticulturae 211: 126-139. doi:10.1016/j.scienta.2016.08.016.

NAKASONE KK. 2007. Morphological and molecular studies on Resinicium s.str. Canadian Journal of Botany 85: 420-436. doi: 10.1139/b07-035.

Negrão DR, Silva-Júnior-Taf DA, Passos-Jr DES, Sansígolo CA, Minhoni-Mt-De A \& Furtado EL. 2014. Biodegradation of Eucalyptus urograndis wood by fungi. International Biodeterioration and Biodegradation 89: 95-102. doi:10.1016/j.ibiod.2014.01.004.

Nilsson RH, Hyde KD, Pawłowska J et al. Improving ITS sequence data for identification of plant pathogenic fungi. FungalDiversity 67: 11-19. doi:10.1007/s13225014-0291-8.

Oliveira AMF, Lelis At DE, Lepage ES et al. 1986. Agentes destruidores da madeira. Pp 99-256 in Lepage ES et al. (eds) Manual de preservação de madeiras. Instituto de Pesquisas Tecnológicas do Estado de São Paulo, São Paulo.

Ortiz R, Navarrete J, Oviedo C et al. 2013. White rot Basidiomycetes isolated from Chiloé Park in Los Lagos region, Chile. Antonie van Leeuwenhoek 104: 1193-1203. https://doi.org/10.1007/s10482-0130041-z.

Pangallo D, Chovanová K, Šimonovičová A \& Ferianc P. 2009. Investigation of microbial community isolated from indoor artworks and air environment: identification, biodegradative abilities, and DNA typing. Canadian
Journal of Microbiology 55: 277-287. doi:10.1139/ w08-136.

Pinho DB, Firmino AL, Ferreira-Junior WG \& Pereira OL. 2012. An efficient protocol for DNA extraction from Meliolales and the description of Meliola centellae sp. nov. Mycotaxon 122: 333-345.

Riley R, Salamov AA, Brown DW et al. 2014. Extensive sampling of basidiomycete genomes demonstrates inadequacy of the white-rot/brown-rot paradigm for wood decay fungi. Proceedings of the National Academy of Sciences of the United States of America 111: 9923-9928. doi:10.1073/pnas.1400592111.

Schubert M, Volkmer T, Lehringer C \& Schwarze FWMR. 2011. International Biodeterioration \& Biodegradation Resistance of bioincised wood treated with wood preservatives to blue-stain and wood-decay fungi. International Biodeterioration and Biodegradation 65: 108-115. https://doi. org/10.1016/j.ibiod.2010.10.003.

Shrestha P, Khanal SK, PomettoiI AL \& Van Leeuwen J. 2009. Enzyme production by wood-rot and soft-rot fungi cultivated on corn fiber followed by simultaneous saccharification and fermentation. Journal of Agricultural and Food Chemistry 57: 4156-4161. doi:10.1021/jf900345n.

Silva LF, Paes JB, De Jesus Junior WC, Oliveira Jt Da S, Furtado EL \& Alves FR. 2014. Deterioração da madeira de Eucalyptus spp. por fungos xilófagos. Cerne 20: 393-400. doi:10.1590/010477602014200 31462.

Skyba O, Cullen D, Douglas CJ \& Mansfield SD. 2016. Gene expression patterns of wood decay fungi Postia placenta and Phanerochaete chrysosporium are influenced by wood substrate composition during degradation. Applied and Environmental Microbiology 82: 4387-4400. doi:10.1128/AEM.00134-16.

Thaler N, Lesar B, Kari M \& Humar M. 2012. Bioincising of Norway spruce wood using wood inhabiting fungi. International Biodeterioration and Biodegradation 68: 51-55. https://doi.org/10.1016/j.ibiod.2011.11.014.

Toljander YK, Lindahl BD, Holmer L \& Högberg NOS. 2006. Environmental fluctuations facilitate species co-existence and increase decomposition in communities of wood decay fungi. Oecologia 148: 625-631. doi:10.1007/s00442-006-0406-3.

Tortella GR, Rubilar O, Gianfreda L, Valenzuela E \& DieZ MC. 2008. Enzymatic characterization of Chilean native wood-rotting fungi for potential use in the bioremediation of polluted environments with chlorophenols. World Journal of Microbiology and Biotechnology 24: 2805-2818. doi:10.1007/s11274008-9810-7.

Urairuj C, Khanongnuch C \& Lumyong S. 2003. Ligninolytic enzymes from tropical endophytic Xylariaceae. Fungal Diversity 13: 209-219.

White TJ, Bruns T, LeE S \& TAYlor J. 1990. Amplification and direct sequencing of fungal ribosomal RNA genes for phylogenetics. PCR Protocols: A Guide to Methods and Applications 315-322. doi:10.1016/B978-0-12372180-8.50042-1.

Wu J, XIAo YZ \& Yu HQ. 2005. Degradation of lignin in pulp mill wastewaters by white-rot fungi on biofilm. Bioresource Technology 96: 1357-1363. doi:10.1016/j. biortech.2004.11.019. 